\title{
Economic inclusion of un-bankable micro-scale traders in Indonesian traditional market: learning from micro-scale traders in Islamic financial co- operative
}

\author{
Iwan Prasetyo ${ }^{1}$, Raphaella Dewantari Dwianto ${ }^{1, *}$ \\ ${ }^{1}$ Departement of Sociology, Universitas Indonesia, Jakarta 16424, Indonesia
}

\begin{abstract}
Central Bank in Indonesia has launched an inclusive economy strategy, whose aim includes people of low income and micro-scale business owner. Microscale traders in rural traditional market in Indonesia in general face the challenge of limited access to formal financial institution, since they are considered un-bankable. The difficulty of accessing capital from banking financial institutions becomes an obstacle to increasing the scale of their business. The situation often causes market micro-scale traders to fall into the practice of loan sharks. As an alternative, traditional market traders turn to Islamic microfinance co-op. This paper studies the case of micro-scale traders in a rural are in Central Java, in their relationship with a local Islamic Financial Cooperative (Syariah Baitul Maal Wat Tamwil) that provides financial products/services. Using qualitative approach, the findings field research conducted from 2016 until 2018 points out to the success of Islamic Financial Coop as an inclusive financial institution for the local micro-scale traders, which supports promotion of sustained economic growth and productivity, despite (or, because of) its traditional way of trust-building.
\end{abstract}

\section{Introduction}

The Government of Indonesia has launched the National Strategy for Financial Inclusion in Indonesia, in 2012. The program continued until 2014, and then refined with the Nawacita program of the President of the Republic of Indonesia as stipulated in Presidential Regulation No. 82 of 2016. This financial inclusion aims to encourage people who have not been touched by the bank to be able to use banking services such as savings, payments and transfers of credit and insurance funds [1]. This is similar to what was stated by Khan who stressed that the implementation of financial inclusion will facilitate access to financial and credit services on targeted subjects, i.e. that the poor and low-income people, at affordable costs. This is supported by bank account access supported by deposit insurance, affordable credit access and payment systems [2]. The inclusion of financial policies is an important policy, especially since the percentage of population with bank accounts in Indonesia, Indonesia turns out to be the last place when compared to Singapore, Thailand, Malaysia, China and India.

In this national strategy on inclusive finance in Indonesia, there are six important pillars: financial education, public financial facilities, mapping of financial information, policies, intermediation facilities and distribution channels, and consumer protection. The strategy is in-line with Sustainable Development Goals, which supports promotion of sustained economic growth and productivity. In

${ }^{*}$ Corresponding author: raphaella.dwianto@ui.ac.id 
this financial inclusion there are at least four systems that is essential and vital for the people, namely savings, credit / financing, payment and insurance systems [3].

In Indonesia, the implementation of this financial inclusion strategy was reviewed by the International Finance Institute (IIF). The financial inclusion program in Indonesia failed to meet the expectations [4]. President Jokowi was determined to push Laku Pandai financial inclusion programs that are projected to provide social and economic benefits to the people who are still being excluded from financial services. To make all Indonesian be bankable is crucial, since in the future government assistance programs will be distributed through bank accounts. Moreover, Indonesia has a geography that consists of thousands of islands, which is a challenge for programs that aim to improve access of people who are not eligible to be financed by banks (unbankable) to become bankable (bankable).

Table 1. List of countries with the percentage of population owning accounts at the banking financial institution in 2012 [5].

\begin{tabular}{|c|l|c|c|}
\hline No & Countries & $\begin{array}{c}\text { Percentage of Population } \\
\text { Owning Accounts }\end{array}$ & $\begin{array}{c}\text { Number of } \\
\text { population }\end{array}$ \\
\hline 1 & Singapore & $98,2 \%$ & 5,5 million \\
\hline 2 & Thailand & $72,7 \%$ & 65,1 million \\
\hline 3 & Malaysia & $66,2 \%$ & 30,8 million \\
\hline 4 & China & $63,8 \%$ & 1.338 million \\
\hline 5 & India & $35,2 \%$ & 1.251 million \\
\hline 6 & Indonesia & $19,6 \%$ & 239,9 million \\
\hline
\end{tabular}

On the other hand, the central bank Bank Indonesia (BI) has recorded a high contribution of gross domestic product (GDP) from Micro, Small and Medium Enterprises (MSMEs) reaching 59\% of the total. However, this is not comparable to the constraints faced by SMEs, especially in obtaining capital from banking financial institutions. Capital constraints always is a barrier for $50 \%$ of MSMEs in Indonesia. This also appears in the statement of the Indonesian Guarantee Company Association (Asippindo) that by the end of 2015 there would be $82 \%$ from the total number of micro, small and medium enterprises (MSMEs) still experiencing such barrier (of access to external funding for business capital). This is due to the lack of resources owned by business actors in the form of assets required as collateral by the banking sector and also due to the fact that the MSME sector has a high risk of credit failure. Needless to say, small and micro business actors are economic actors who have limited capacity.

Banking services that provide finance for business capital cannot yet reach those small and micro business actors. The reason is, most of micro, and small enterprises (MSEs) are not yet bankable. The requirements from the banking sector are difficult to be fulfilled by the business actors in this sector. Thus, the high risk in terms of return on capital becomes the concern of the banks on the return of loans that have been disbursed. According to national data around 50.7 million business units are vulnerable to financing.

Judging from the prospects and funding service institutions for improving inclusion financial services that have been running so far, there are actually institutions that are very prospective to increase the level of financial inclusion in the community. The institution called Baitull Tamwil Watt Mall or often referred to as BMT. BMT stands for the words Integrated Business Enterprise or Baitul Maal wa Tamwil, which is a microfinance institution that operates based on sharia principles. BMT as the name implies consists of two functions, namely:

1. Baitut tamwil (property development house), with main task of developing productive businesses and investments in improving the economic quality of micro and small entrepreneurs, among others by encouraging savings and supporting financing of economic activities..

2. Baitul maal (property house), with main task of receiving deposits from zakat, infaq and alms funds and optimizes its distribution in accordance with its regulations and mandates.

In addition, BMT also aim at improving the welfare of its members [6]. BMT as an institution that develops the business sector with a profit-sharing system that is oriented at micro, small-scale 
businesses with the aim of reducing poverty [7]. BMT provides capital assistance to productive small business actors with profit sharing patterns based on mutual agreement [8].

\section{Methodology}

The study was conducted with the main focus on BMT Al Quddus with its customers i.e. traditional rural market micro-traders in Selopampang Village, Temanggung Regency in Central Java Province of Indonesia. This study used a qualitative approach with the intention to analyze a process, social interaction of people involved in financial products and services provided by BMT Al Quddus with traditional village market micro-traders, in an inclusive financial framework. In addition, this research is also to find out the mutual trust the norm that develops in the community and the social relations between the two (network). Data collection was carried out by means of observation, interviews and review of documents / publications / reports. The research was conducted with the main focus on BMT Al Quddus and the micro-traders of Selopampang rural traditional market. As the period of data collection and analysis were carried out for 22 (twenty two) month, from August 2016 until May 2018.

\section{Result and Discussion}

\subsection{Inclusive economy strategy in Indonesia}

The National Inclusive Finance Strategy Policy, defines inclusive finance as "the right of everyone to have full access and service from financial institutions in a timely, convenient, informative and affordable manner, with full respect for their dignity. Financial services are available to all segments of society, with special attention to the poor, productive poor, migrant workers and residents in remote areas " [9]. Financial inclusion is a condition where financial service products and services that can be accessed by a layer of poor / low income people are easily without constraints. 'Without problems' means that it is available in terms of facilities by financial institutions and can be accessed by the poor

In Indonesia to realize financial inclusion for the poor / low-income people and in areas where financial services are not yet available, a comprehensive approach is adopted through a national strategic policy better known as The National Strategy for Financial Inclusion (SNKI). In general, this approach to national financial inclusion will cover at least 3 (three) aspects that are interrelated with one another, the first aspect, namely the provision of appropriate service facilities, the availability of financial service infrastructure that can be easily reached by the public considering Indonesia consists of thousands of islands. The second aspect is the provision of suitable products, financial products and services tailored to economic, social and cultural conditions and the needs of the local community. The last aspect is responsible finance, which includes financial education and consumer protection. Providing information about the benefits of financial products and services so that the public can use them carefully, besides the need for community protection that uses financial services / products so that they are more calm and reassuring. This financial inclusion strategy is not only the domain of the duties of Bank Indonesia and the Financial Services Authority, but must involve all institutions to synergize with one another in providing financial products and services to stekeholders who need them. The synergy between institutions will support the success of the national financial inclusion strategy with good governance and structured coordination.

This national financial inclusion strategy has a target group of people, so that they get easy access to financial products / services. The target is none other than the people who have been facing difficulties to access financial products / services, due challenge of distance and of required documents. The ease of access to financial services is expected to reduce poverty and increase community income. The target is divided into population categories and cross categories. This category of population includes low-income poor, working poor and poor but productive people, and people who are almost poor. Whereas those included in the cross category are migrant workers, women and residents who are still in disadvantaged areas. 


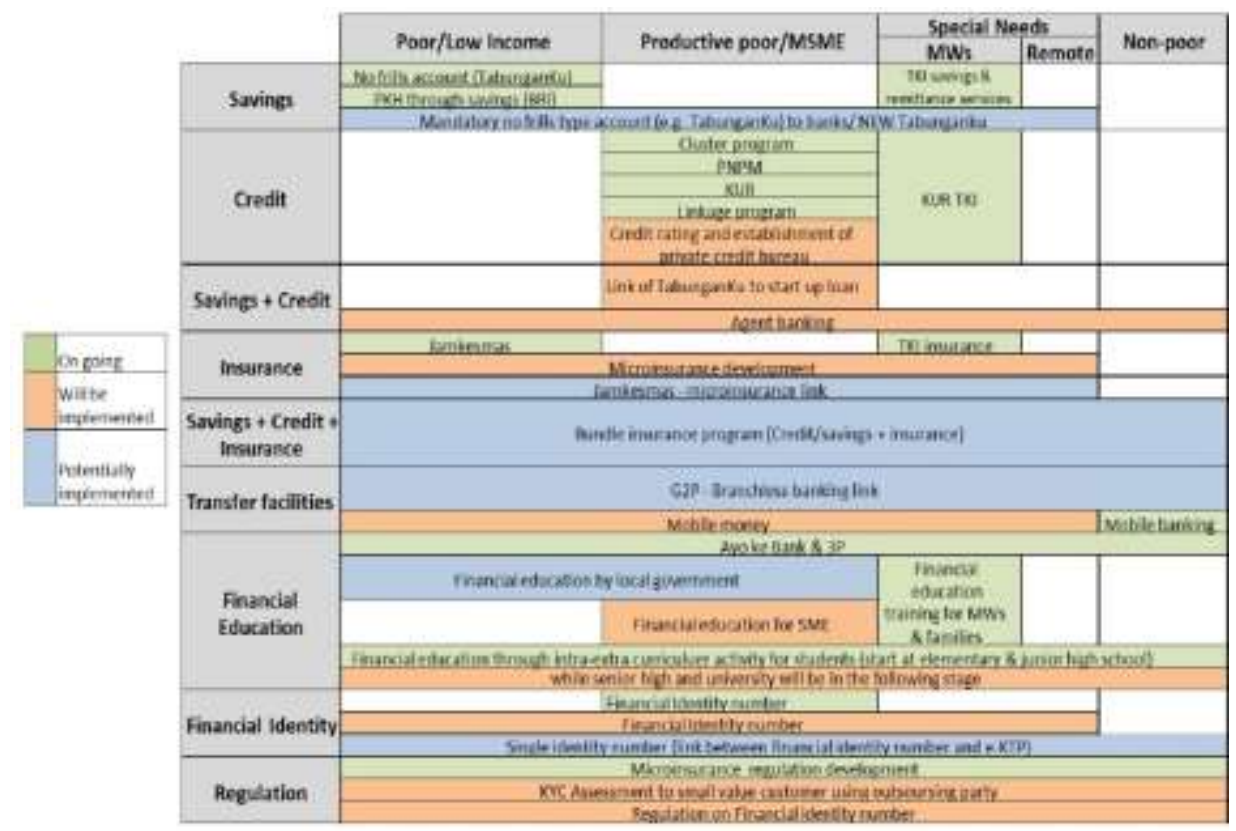

Fig. 1. Inclusive financial target groups [10].

\subsection{The Islamic financial co-op (Syariah Baitul Maal Wat Tamwil /BMT)}

Sharia Savings and Loan Cooperative / Sharia Financial Services Cooperative (KJKS) is a cooperative that has business activities in the field of savings, investment and financing whose business processes are based on sharia principles (Islamic law) with profit sharing agreements. BMT can be categorized in this cooperative, with the requirement in its establishment to have legality / legal entity and as well as the implementation of its business activities have fulfilled the stipulated regulations [11]. The Sharia Financial Services Cooperative (KJKS) has an organizational structure / structure such as other cooperatives.

BMT Al Quddus, established in 1998 is one kind of the sharia microfinance institutions (KJKS). Regarding the history of the establishment of the BMT in Selopampang, before BMT Al Quddus, the first Islamic microfinance institution in Temanggung District was BMT Arrohman established in 1996. During the Asian economic crisis of 1997-1998 which resulted in the rise in number of poverty, PINBUK or the incubation center for small business businesses drew a plan to establish 1,000 BMT Islamic microfinance institution throughout Indonesia, to deal with the poverty. In 1998 BMT Al Quddus was formed with initial membership of 28 people. The BMT was given legal entity status as KSU (Koperasi Serba Usaha or all purpose cooperative) by the Temanggung Regency Cooperative Office, with No. 143 / BH / KDK.11.20 XII 1999, establishment dated December 18, 1999.

This financial institution operates in the Selopampang Village Traditional Market through providing microfinance services / products that adopts the Baitul Maal Wat Tamwil (BMT) work system and a cooperative legal entity. This institution is the backbone for micro and small traders. This BMT provides microfinance savings and microfinance loan services that are affordable for the community. It becomes an alternative to access and use financial services similar to those provided by banking institutions. KJKS BMT Al Quddus has a very significant role in helping micro and small entrepreneurs traditional market traders by providing them with microfinance services. KJKS BMT Al Quddus considers market micro-traders as very productive business actors whose existence has not been optimally touched by banking institutions. Therefore, it is necessary for microfinance institutions to provide services similar to banking institutions. 


\subsection{Micro-scale traders in traditional market with their BMT}

Selopampang district which is the focus of this study, is located on the slopes of Sumbing Mountain, which is more than $200 \mathrm{~m}$ above sea level. Selopampang district in 2014 had a population of 18,357 people consisting of 6,854 men, 6,875 women, 2,311 boys and 2,317 girls (BPS, 2014). It is a new sub-district after regional autonomy law is implemented. Administratively the village is the same as other villages, but this village has different advantages compared to other villages in the vicinity. Selopampang Village is the economic heart of the community in the Tembarak District area. There is a traditional market of Selopampang Village which is the lifeblood of the community's economy. Economic activities in the Selopampang District are dominated by agriculture and trade. Agriculture is the main livelihood with $74.59 \%$ of its residents work as farmers are so the state of the economy is strongly influenced by agriculture. In addition to agriculture, trade and services are the driving force of the people's economy.

Table 2. List of Percentages by Livelihood [12]

\begin{tabular}{|l|l|c|}
\hline No & \multicolumn{1}{|c|}{ Livelihood } & Percentage \\
\hline 1 & Agriculture & $74.59 \%$ \\
\hline 2 & Industry & $2.58 \%$ \\
\hline 3 & Construction & $2.70 \%$ \\
\hline 4 & Trade & $11.07 \%$ \\
\hline 5 & Transportation & $1.47 \%$ \\
\hline 6 & Services & $7.15 \%$ \\
\hline 7 & Other & $0.44 \%$ \\
\hline \multicolumn{2}{|c|}{ Total } & $100 \%$ \\
\hline
\end{tabular}

Traditional Market Selopampang village grew naturally since the Dutch colonial era before Indonesia became independent country. The majority of traders come from villages located close to the market. Merchandise traded is the basic needs of the residents, namely clothing, vegetables, agricultural equipment, building tools, household appliances, financial services, haircut services and so on. The day of buying / selling activities by following the Javanese calendar takes 3 (three) days from the 5 (five) days available, namely, on Pon Day, Legi Day and Kliwon Day.

BMT Al Quddus pay extra attention to micro-scale market traders. 50\% of the total members who take loans are those in the trade sector. In accordance with the initial purpose of the establishment, this institution was established to help financing the productive people who have businesses but find it difficult to get access from existing financial institutions. Traders in this traditional market find it helpful to get additional capital on a very small scale. On average they take loans between 1-5 million rupiah (approximately US\$ 65-100). The provision of inclusive financial services is in the form of opening savings at an affordable cost, saving money without a nominal limit, free administrative fees, picking up ball services, and providing collateral / loans without a certain nominal value. Opening a current savings account with a very affordable initial deposit. By depositing an initial sum of 10,000 rupiah (approximately US\$ 0.65), a BMT member will receive 1 (one) account number. Whereas in a national bank, the initial deposit to get is 1,000,000 rupiah (approximately US\$ 65), which is a burden for traditional market small / micro entrepreneurs. As for the assets of BMT, fund from third parties are increasing in number. These funds are deposits originating from members of this institution. The growth of this funding source strongly reflects the economic conditions of the local community. Twofold increase in deposits occurred in 2011. In that year the economic conditions of the community experienced growth along with the presence of a good tobacco season. 
In addition to its activities as a microfinance savings and loan institution BMT Al Quddus is also a social religious institution that receives and distributes Zakat, Infaq and Shodaqoh (ZIS). BMT Al Quddus as a microfinance institution that serves small businesses, especially market traders, also provides guidance and consultation on the management of money. Consultation is also given when the member applies for loan, from the type of product, the type of installments and the use of the funds for the business. The granting of funding by BMT is for productive activities that will help the members expand their business. In addition to financial consultation, regular Qoran recitations is held every 35 days in Selopampang Mosque which is located near the market and office. Employees, administrators, market traders and the local community can attend this event.

\section{Concluding remarks}

The Al Quddus BMT KJKS has a very important role in supporting micro-scale market traders, in their savings, borrowing, financing and electricity payments. The provision of sharia microfinance product services has been able to support the improvement and sustainability of traditional market traders. For the government, this financial institution supports its strategy to reduce financial exclusion. Easy access to financial service products provided by institutions to market traders is inseparable from the existence of mutual trust and norms that develop in the community, and social network between the two parties.

Islamic religious norms as a basis in the operational activities of the business are the most important fundamental for the management of the BMT. In Selopampang market almost all traders are Moslem. Thus, the financial institution with the sharia system is very appropriate to be implemented. The division of business profits with the profit sharing system is considered to be more just and reassuring. In addition to these two things, the close and almost personal relationships between the BMT and market traders also serves as base in the provision of inclusive financial services. Emotional ties that are intertwined with mutual trust ultimately have an impact on the low level of financial exclusion of traditional market traders. Market traders have the convenience of accessing and using financial services according to their needs both in the form of deposits and financing. The ease of access and use of sharia microfinance services is an alternative way for market traders to get products that meet their needs.

To put it in other words, The provision of sharia microfinance product services has been able to support the improvement and sustainability of traditional market traders, and contribute to sustainable economic growth at the level of everyday life. For the government, this financial institution supports its strategy to reduce financial exclusion. Islamic religious norms as a basis in the operational activities of the business are the most important fundamental. The close and almost personal relationships also serves as base in the provision of inclusive financial services. Emotional ties that are intertwined with mutual trust ultimately have an impact on the low level of financial exclusion of traditional market traders. In strategy for financial inclusion, the BMT case can be referred as one model of implementation.

\section{Acknowledgements}

This work is supported by Hibah PITTA 2018 funded by DRPM Universitas Indonesia No.5000/UN2.R3.1/HKP.05.00/2018

\section{References}

1. A. Hannig and S. Jansen. Financial Inclusion and Financial Stability: Current Policy Issues. ADBI Working Paper 259. Tokyo: Asian Development Bank Institute. Available: http://www.adbi.org/workingpaper/2010/12/21/4272.financial.inclusion.stability.policy.issues/ (2010) 
2. H.R. Khan, Financial Inclusion and Financial Stability: Are They Two Sides of the Same Coin? Address by Shri H. R. Khan, Deputy Governor of the Reserve Bank of India, at BANCON 2011, organized by the Indian Bankers Association and Indian Overseas Bank, Chennai, India, 4 November (2011)

3. World Bank. Indicators of Financial Access - Household - Level Surveys (2005)

4. B. D. Gupta and D.Dahlberg, Indonesia: Getting Serious About Financial Inclusion (The Institute of International Finance, Inc, 2015)

5. http://finance.detik.com/read/2012/05/14/174753/1916933/5/soal-jumlah-rekening-bank-ripaling-ketinggalan-di-asean (2012)

1. A. Amin, Pedoman Pendirian BMT. (Pinbuk Press, Jakarta, 2004)

2. N. S. Ismaniyati, Aspek Aspek Hukum BMT.Bandung (Citra Aditya Bakti, 2010)

3. Bank Indonesia. "Booklet Keuangan Inklusif". Departemen Pengembangan Akses Keuangan dan UMKM BI. (2014)

4. TNP2K, Modul Meningkatkan Pemberdayaan Masyarakat melalui Koperasi Lembaga Keuangan Mikro (Sekretariat Tim Nasional Percepatan Penanggulangan Kemiskinan, Jakarta, 2015)

5. Peraturan Menteri Negara Koperasi dan UMKM Nomor 35.2/PER/M.KUKM/X/2007 tentang Pedoman Standar Operasional Manajemen Koperasi Jasa Keuangan Syariah Dan Unit Jasa Keuangan Syariah Koperasi.

6. https://temanggungkab.bps.go.id/ (2017) 